\title{
Complications of Bone Plating Following Different Facial Bones Fractures
}

\author{
Ali R. Al-Hammami, (B.D.S, H.D.D) \\ Maxillofacial Unit, Al-Sadir Medical City, Najaf, Iraq \\ Auday M. Al-Anee, (B.D.S, F.I.B.M.S.) \\ Lecturer, Department of Oral and Maxillofacial Surgery, \\ Baghdad College of Dentistry, University of Baghdad, Iraq \\ Thair Abdul Lateef, (B.D.S., H.D.D., F.I.B.M.S.) \\ Assistant Professor, Department of Oral and Maxillofacial Surgery, \\ Baghdad College of Dentistry, University of Baghdad, Iraq \\ Adil Al-khayat, (B.D.S., M.Med.Sc, F.D.S.R.C.S.)
}

Assistant Professor, Head of Maxillofacial Council of Iraqi Board of Medical

Specializations, Baghdad

Doi: 10.19044/esj.2018.v14n6p351 URL:http://dx.doi.org/10.19044/esj.2018.v14n6p351

\section{Abstract}

The Aim of our study was to evaluate the complication of bone plating fixation used for treatment of multiple type of facial fracture, reconstruction procedure and bone graft in maxillofacial trauma. This prospective study was performed on 42 patients to evaluates complications of the bone plates had been used in fixation of multiple facial fractures, between October 2013 and March 2015, The age of the patients ranged from $17-65$ years The mean age of the patients was $(31.7 \pm 9.4)$ years. There were 31 males and 11 females, with male to female ratio (2.81:1), patients were followed up for minimum 6 months. Seventy-one plates were inserted over 17 months. Among the 42 patients there were 45 fracture sites, $26(57.8 \%)$ were mandibular fractures, 15 (33.3\%) were ZMC fractures, and four $(8.9 \%)$ were maxillary; it is worth mentioning that some patients had fracture at more than one site. Complications due to fracture fixation with bone plating were 33 represented $46.5 \%$ of the total 71 plates inserted, which included Infection/wound dehiscence 15 (21.1\%), Discomfort/ palpability 9 (12.7\%), Plate exposure 4 (5.6\%), hardware failure (broken plate \& loosening screw) 1 (1.4\%), Cold/heat intolerance $3(4.2 \%)$ and Pain (TMJ) account for one plate (1.4\%). According to this study, there will be a need for hardware removal in a portion of patients treated with metallic osteosynthesis devices. This study states that the infection is most common reason for plate removal, followed by 
discomfort due to cold/heat climate, particularly in those facial regions that provide only thin soft tissue cover over the plate.

Keywords: Facial bones fractures, zygomaticomaxillary complex (ZMC) trauma, bone plate complication

\section{Introduction}

Techniques for treatment of some facial fractures have evolved significantly. These techniques have ranged from closed reduction with maxillomandibular fixation (MMF), to open reduction with wire osteosynthesis, to open reduction with either rigid internal fixation or adaptive miniplate fixation ( Chritah, Lazow, \& Berger, 2005).

During the 20th century, a number of critical innovations resulted in the improved management of facial bones fractures. The first was the introduction of penicillin during the World War II, which encouraged the open reduction of fractured bones and hence improvement in the accuracy of fracture alignment (Dimitroulis, 2002).

The second innovation was the introduction of miniature bone plates and screws in the 1960s and 1970s, which permitted the rigid internal fixation of fracture sites and hence the abolition of postoperative intermaxillary wire fixation (IMF). Rigid internal fixation and early return to function have replaced the use of wire osteosynthesis and prolonged use of maxillomandibular fixation (Kumaran \& Thambiah, 2011)

Notable complications include infection, erosion of soft tissue, exposure, and discomfort. Discomfort from titanium plating spans a wide range of severities from simple palpability over sensitive areas of the face to cold intolerance and pain. These complications often necessitate secondary operative procedures to remove previously installed hardware. Preexisting hardware can also complicate secondary reconstructive procedures such as bone grafting and osteotomies (Nagase, Courtemanche, \& Peters, 2005).

The rates of plate removal in craniofacial surgery vary from $12 \%$ to $18 \%$.The most common reason for removal is infection, accounting for approximately half of all plate removals cited in other studies. Discomfort/palpability is the next most commonly cited reason for plate removal, accounting for approximately a sixth of all plate removals (Bhatt \& Langford, 2003).

\section{Aim of study}

To evaluate the complications of bone plating fixation used for treatment of multiple type of facial fracture, reconstruction procedure and bone graft in maxillofacial trauma. 


\section{Patients And Methods}

This prospective study conducted at the Department of Oral and Maxillofacial Surgery in Al-Shaheed Ghazi Al-Hariri Teaching Hospital for Specialized Surgeries in Baghdad, during the period from October 2013 to March 2015. All patients with different facial fractures, reconstruction or bone graft procedures that were treated surgically using different types of bone plates were followed up for any complications associated with one or more of the bone plates used. Every patient with one or more of the following criteria considered as having a complicated bone plate:

$\checkmark \quad$ Pain at the site of plate

$\checkmark \quad$ Infection and wound dehiscence

$\checkmark \quad$ Plate extrusion

$\checkmark \quad$ Discomfort/palpability

$\checkmark \quad$ Intolerance to cold/heat

$\checkmark \quad$ Nerve paresthesia

$\checkmark \quad$ TMJ pain/clicking

\section{Exclusion criteria} the study:

Patients with one or more of the following criteria were excluded from × Patient less than 16 years old, because those patients be in progressive growth period

$\boldsymbol{x} \quad$ Plates in patients need radiotherapy

$x \quad$ Plate at osteotomy site

x Plate interfering with dental implants

\section{Follow up}

Patients were followed up in the outpatient clinic after surgery at 1 week, 2 weeks, 4 weeks and then monthly after surgery for a minimum 6 month period. Suture removal during this follow up, bone and soft tissue healing were assessed clinically \& radiographically in addition to recording postoperative complications in term of:
- Infection
- Wound dehiscence
- Malunion
- Nonunion
- $\quad$ Paresthesia of mental nerve, infraorbital nerve\& other nerve
- Tooth root damage
- Osteomyelitis
- $\quad$ Exposure of bone plate(s)
- $\quad$ Plate palpability/ Sensation of foreign body
- $\quad$ Intolerance to cold and/or heat 
- $\quad$ Hardware failure (broken plate \& loosening screw)

- $\quad$ Need for plate removal

\section{Statistical analysis}

Data of patients were entered and analyzed by using the statistical package for social sciences (SPSS) version 22, 2014. Descriptive statistics were presented as frequencies, proportions (percentage), mean and standard deviation. Fisher's exact test was used to compare frequencies, level of significance, P.value $\leq 0.05$ was considered as significant.

\section{Results}

This study included 42 patients with multiple facial fractures. The age of patients ranged from $17-65$ years. The mean age of the patients was $(31.7 \pm$ 9.4) years. It had been observed that maxillofacial injuries were more frequent, (47.6\%), at age of $21-30$ years. The age distribution was shown in table (1). Regarding the gender distribution, there were 31 males (73.8\%) $11(26.2 \%)$ females, with male to female ratio of (2.81:1). The gender distribution was shown in figure (1). Seventy one plates were inserted over 17 months. Among the 42 patients there were 45 fracture sites, 26 (57.8\%) were mandibular fractures, $15(33.3 \%)$ were zygamtico-maxillary fractures (ZMC), and four $(8.9 \%)$ were maxillary; it is worth mentioning that some patients had fracture at more than one site.

Table (1) Age distribution of bone plate fixation

\begin{tabular}{|c|c|c|}
\hline Age (years) & No. of patients & $\%$ \\
\hline$\leq 20$ & 5 & 11.90 \\
\hline $21-30$ & 20 & 47.60 \\
\hline $31-40$ & 8 & 19.05 \\
\hline $41-50$ & 3 & 7.16 \\
\hline $51-60$ & 4 & 9.53 \\
\hline$>60$ & 2 & 4.76 \\
\hline Total & 42 & 100.0 \\
\hline Mean & $31.7 \pm 9.4$ & - \\
\hline Range & $17-65$ & - \\
\hline
\end{tabular}




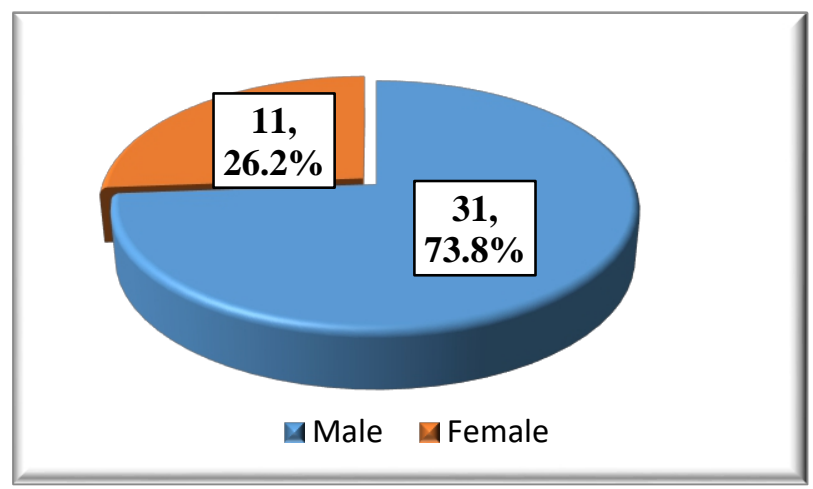

$(\mathrm{N}=42)$

Figure (1): Gender distribution of bone plate fixation

Complications due to fracture fixation with bone plating were 33 represented $46.5 \%$ of the total 71 plates inserted, which included Infection/wound dehiscence 15 (21.1\%), Discomfort/ palpability 9 (12.7\%), Plate exposure 4 (5.6\%), hardware failure (broken plate \& loosening screw) 1 (1.4\%), Cold/heat intolerance $3(4.2 \%)$ and Pain (TMJ) 1 (1.4\%), on the other hand, no complication had been developed in the remaining 38 plates $(53.5 \%)$.

Table (2) shows the distribution of the 33 complicated plates (out of 71 plates) according to the etiology of fracture, as it shown in this table that, for Missiles, the most common complication, were 13 (52\%) plates associated with infection/wound dehiscence, while the least complication, was 1 (4\%) plate, associated with hardware failure and TMJ pain. For Sport, the most common complication, were $2(66.67 \%)$ plates associated with discomfort/palpability, while the least was1 (33.33\%) plate, associated with infection/wound dehiscence.

\begin{tabular}{|c|c|c|c|c|c|c|}
\hline \multirow[b]{3}{*}{$\begin{array}{l}\text { Plates related- } \\
\text { Complication }\end{array}$} & \multicolumn{6}{|c|}{ Etiology } \\
\hline & \multicolumn{2}{|r|}{ Missiles } & \multicolumn{2}{|r|}{$\mathrm{RTA}^{*}$} & \multicolumn{2}{|r|}{ Sport } \\
\hline & No. & $\begin{array}{c}\% \text { of } \\
\text { complicated } \\
\text { plates }\end{array}$ & No. & $\begin{array}{c}\% \text { of } \\
\text { complicated } \\
\text { plates }\end{array}$ & No. & $\begin{array}{c}\% \text { of } \\
\text { complicated } \\
\text { plates }\end{array}$ \\
\hline $\begin{array}{l}\text { Infection/wound } \\
\text { dehiscence }\end{array}$ & 13 & 52 & 1 & 20 & 1 & 33.33 \\
\hline Discomfort/palpability & 5 & 20 & 2 & 40 & 2 & 66.67 \\
\hline Plate exposure & 3 & 12 & 1 & 20 & 0 & 0.0 \\
\hline $\begin{array}{l}\text { Hardware failure(broken } \\
\text { plates \&loosening } \\
\text { screws) }\end{array}$ & 1 & 4 & 0 & 0.0 & 0 & 0.0 \\
\hline Cold/heat intolerance & 2 & 8 & 1 & 20 & 0 & 0.0 \\
\hline TMJ pain & 1 & 4 & 0 & 0.0 & 0 & 0.0 \\
\hline $\begin{array}{c}\text { Total complications per } \\
\text { etiology }\end{array}$ & 25 & 100.0 & 5 & 100.0 & 3 & 100.0 \\
\hline & & $\begin{array}{l}\text { no. of comp } \\
\text { RTA }=\text { Road }\end{array}$ & ed & $\begin{array}{l}\text { tes }(n)=33 \\
\text { cident }\end{array}$ & & \\
\hline
\end{tabular}

Table (2) Etiology and plate's related- complications 
For RTA, the most common complication, were 2 (40\%) plates associated with discomfort/palpability, while the least complication, was 1 (20\%) plate, associated with infection/wound dehiscence, cold/heat intolerance, and plate exposure respectively.

Table (3) shows the distribution of the 33 complicated plates (out of 71 plates) according to the types of fracture, as it shown in this table that, for Comminuted type, the most common complication, were $12(50 \%)$ plates associated with complication, was 1 (4.185\%) plate, associated with hardware failure and TMJ pain.

\begin{tabular}{|c|c|c|c|c|c|c|}
\hline & \multicolumn{5}{|c|}{ Type of fracture } \\
\cline { 2 - 7 } Complication & No. & $\begin{array}{c}\text { Comminuted } \\
\text { complicated } \\
\text { plates }\end{array}$ & No. & $\begin{array}{c}\text { Compound } \\
\text { complicated } \\
\text { plates }\end{array}$ & No. & $\begin{array}{c}\% \text { of } \\
\text { complicated } \\
\text { plates }\end{array}$ \\
\hline $\begin{array}{c}\text { Infection/ } \\
\text { wound dehiscence }\end{array}$ & 12 & 50 & 2 & 28.6 & 1 & 50 \\
\hline $\begin{array}{c}\text { Discomfort } \\
\text { /palpability }\end{array}$ & 5 & 20.8 & 4 & 57.1 & 0 & 0.0 \\
\hline Plate exposure & 3 & 12.5 & 0 & 0.0 & 1 & 50 \\
\hline Hardware failure & 1 & 4.185 & 0 & 0.0 & 0 & 0.0 \\
\hline $\begin{array}{c}\text { Cold/heat } \\
\text { intolerance }\end{array}$ & 2 & 8.33 & 1 & 14.3 & 0 & 0.0 \\
\hline TMJ pain & 1 & 4.185 & 0 & 0.0 & 0 & 0.0 \\
\hline $\begin{array}{c}\text { Total complications } \\
\text { per type of fracture }\end{array}$ & 24 & 100 & 7 & 100 & 2 & 100 \\
\hline \multicolumn{7}{|c|}{ Total no. of complicated plates(n)=33 } \\
\hline \multicolumn{7}{|c|}{}
\end{tabular}

Table (3) Type of fracture and plate's related- complication.

For Compound type, the most common complications were 4 (57.1\%) plates associated with discomfort/palpability, infection/wound dehiscence, while the least was $1(14.3 \%)$ plate, associated with cold/heat intolerance.

For simple type, the complications, were equal (50:50\%), one plate for each of infection/wound dehiscence, and plate exposure.

Plates were removed in 22 patients represented $52.4 \%$ of the studied group, of them males were $14(63.6 \%)$ and females were 8 (36.4\%). From other point of view, the total number of plates removed was 28 plates, resulting in a $66.7 \%$ hardware removal rate per patient, or a $39.4 \%$ removal rate per plate, table (4).

Table (4) Distribution of plates removed and removal rates.

\begin{tabular}{|c|c|c|c|}
\hline Variable & No. & $\begin{array}{c}\text { Removal rate per } \\
\text { patient }(\mathrm{N}=42)\end{array}$ & $\begin{array}{c}\text { Removal rate per } \\
\text { plate }(\mathrm{N}=71)\end{array}$ \\
\hline Patients had removed plates & 22 & $52.4 \%$ & $31.0 \%$ \\
\hline Plates removed & 28 & $66.7 \%$ & $39.4 \%$ \\
\hline
\end{tabular}


patients

Removal rate per patient $=$ number of plates removed $/$ total number of plates

Removal rate per plate $=$ number of plates removed $/$ total number of

Table (5) shows the distribution of the 28 complicated plates removed (out of 71 plates) according to the sites of fracture. As it shown in this table, $19(67.9 \%)$ plates removed in those with mandibular fractures, one plate $(3.6 \%)$ in maxillary fractures, and 8 plates removed $(28.5 \%)$ in ZMC, additionally the removal rate according to these sites when calculated from the total (71 plates) were $26.8 \%, 1.4 \%$, and $11.3 \%$, respectively.

On the other hand, the complications related to plates removal were summarized in table (6) these included Infection/wound dehiscence 15 $(53.6 \%)$, Discomfort $9(32.1 \%)$ and plate exposure $4(14.3 \%)$, furthermore, this table shows the distribution of plates removed due to different complications according to the site of fractures, where, out of the 19 plates removed in patients with mandibular fractures, $13(68.4 \%)$ were due to infection/wound dehiscence, 3 (15.8\%) due to discomfort and $3(15.8 \%)$ due to plate exposure .

Of the patients with Midfacial fracture (ZMC, and maxillary fractures) who had plates removed, $2(22.2 \%)$ due to infection/wound dehiscence 6 $(66.7 \%)$ due to discomfort and $1(11.1 \%)$ due to plate exposure.

By using the statistical tests, it had been significantly found that infection/wound dehiscence was more frequent with mandibular fractures than mid facial $(\mathrm{P}=0.028)$, while discomfort was significantly more frequent with midfacial fractures than mandibular, $(\mathrm{P}=0.013)$, and no significant difference had been found in plate exposure $(\mathrm{P}=0.62)$.

Table (5) Distribution of plates removed according to the site of fractures.

\begin{tabular}{|c|c|c|c|}
\hline Site & $\begin{array}{c}\text { Number of } \\
\text { plates removed }\end{array}$ & $\begin{array}{c}\% \text { (from 28 removed } \\
\text { plates) }\end{array}$ & $\begin{array}{c}\text { Removal rate from total 71 } \\
\text { plates }\end{array}$ \\
\hline Mandibular fracture & 19 & $67.9 \%$ & $26.8 \%$ \\
\hline Maxillary fracture & 1 & $3.6 \%$ & $1.4 \%$ \\
\hline ZMC & 8 & $28.5 \%$ & $11.3 \%$ \\
\hline Total & 28 & $100.0 \%$ & $39.5 \%$ \\
\hline
\end{tabular}

Table (6) Distribution of complications related to plates removal according to the site of fracture.

\begin{tabular}{|c|c|c|c|c|c|c|c|}
\hline \multirow{2}{*}{ Complication } & \multicolumn{2}{|c|}{$\begin{array}{c}\text { Mandibular } \\
\text { fracture }(\mathrm{N}=19)\end{array}$} & \multicolumn{2}{c|}{$\begin{array}{c}\text { Mid facial } \\
\text { fracture }(\mathrm{N}=9)\end{array}$} & \multicolumn{2}{|c|}{ Total } & $\begin{array}{c}\text { P. } \\
\text { value }\end{array}$ \\
\cline { 2 - 9 } & No. & $\%$ & No. & $\%$ & No. & $\%$ & \\
\hline $\begin{array}{c}\text { Infection/wound } \\
\text { dehiscence }\end{array}$ & 13 & $68.4 \%$ & 2 & $22.2 \%$ & 15 & $53.6 \%$ & $\mathbf{0 . 0 2 8}^{*}$ \\
\hline Discomfort & 3 & $15.8 \%$ & 6 & $66.7 \%$ & 9 & $32.1 \%$ & $\mathbf{0 . 0 1 3}^{*}$ \\
\hline Plate exposure & 3 & $15.8 \%$ & 1 & $11.1 \%$ & 4 & $14.3 \%$ & 0.62 \\
\hline Total & 19 & $100.0 \%$ & 9 & $100.0 \%$ & 28 & $100.0 \%$ & \\
\hline
\end{tabular}

* P.value is significant 
Figure (2) shows the distribution of time of plate removal, where out of the 28 plates removed, 8 plates $(28.6 \%)$ were removed within 6 months, 9 plates $(32.1 \%)$ were removed after $6-12$ months and 11 plates $(39.3 \%)$ were removed after $13-17$ months.

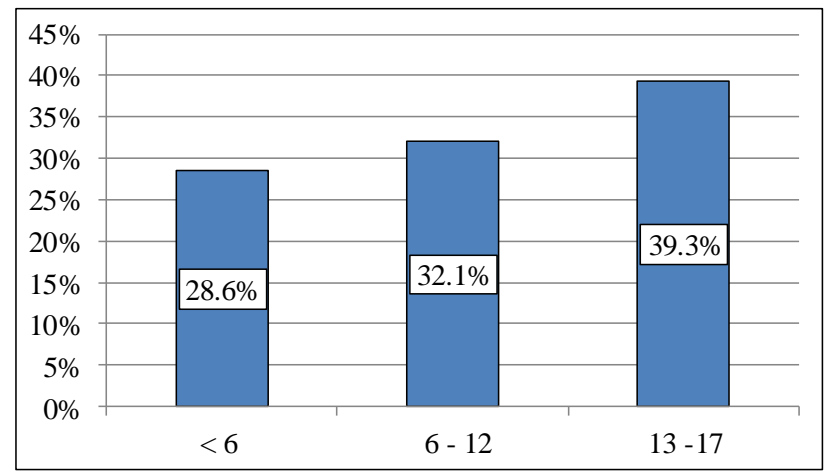

Figure (2): Proportional distribution of time of plate's removal.

\section{Discussion}

This study showed that there is higher number of males, 31 patients (73.80\%) suffered from maxillofacial fractures compared to females, 11patients $(26.20 \%)$. This may be due to that most of the females staying in door for housework or office work, and that they drive less frequent and more carefully compared to the males. Moreover, females only occasionally participate in trading, industrial work, Iraqi army or sports. These lead to less trauma exposure to the females.

Most of patients in this study suffered from maxillofacial fractures were of the young age. The highest being the age group ranged from 21-30 years old, were 20 patients (47.60\%) and the least was the age group 61-70 years old, 2 patients (4.76\%). These groups of young people are being violent and immature. They like the thrill of driving and predisposed to unreasonable road traffic accidents. In addition, the increasing trend of war \& bomb injuries in Iraq, most of them are of this age group.

These findings were consistent with the findings of the studies by Pohchi A. et al. (2013) (167/447 patients, 37.4\%), Chandra Shekar B R and Reddy CVK (2008), and Goyal et al. (2011).

The most frequent fracture site in our study was the mandibular fracture, 26(57.8\%) \{ parasymphysis, body, and the angle of mandible \}, this due to the fact that parasymphysis and the angle of mandible are the more prominent structures on the mandible which is coincide with the study done by Prabhakar et al. (2011), and Goyal et al.( 2012).

ZMC fractures, 15 (33.3\%) were the most frequent fracture site among the Midfacial fractures which is coincide with the study done by Al-Khateeb $\mathrm{T}$ and Abdullah FM (2007), and followed by 4 (8.9\%) were maxillary 
fractures . In a study done by Lee et al. (2009), (12) nasal bone fracture is the most fractured site at the Midfacial fractures, which was not in coincidence with this study.

This study revealed that the most common complication of fracture fixation with bone plating was infection/wound dehiscence $15(21.1 \%)$, and this close to result of Bakathir et al. (2008), was (24.8\%), and Rana et al. (2012), was (51\%), this study differs from Nagase et al.(2005), who had stated the most common cause is discomfort/ palpability and it's the second issue of complication of fracture fixation with bone plating in our study, was $9(12.7 \%)$.

The study also shown that the most common infection-related complications occurred in comminuted and compound fractures, and this close to Malanchuk VO and Kopchak AV (2007), in which the percentage was 35\%.

On this study the third complication of fracture fixation with bone plating was plate extrusion 4 (5.6\%) and this close to result of Francel et al. (1992).

This study is consistent with Longwe et al. (2010) and Bolourian et al. (2002) whom stated in their articles that plate exposure can be caused by different factors including trauma ,smoking, and poor oral intake, drug and alcohol use.

This study reveals that the most common infection-related complications occurred on comminuted fracture, 12 (50\%) plates associated with infection/wound dehiscence, and the preexisting medical disorders were smoking and chronic alcohol abuse, poor oral hygiene, and poor dental status and this close to Malanchuk VO and Kopchak AV( 2007), (35\%).

In this study, $19(67.9 \%)$ plates removed in those with mandibular fractures (body, followed by symphyseal, then by angle), and this the most common site of plate removal and this study resulted in differs from Nagase et al. (2005), who reported in their article, the most common site was parasymphyseal and angle respectively, and close to Ellis E. (1994); Baker et al. (1997) and Rehman et al. (2009), who stated plates removal due to infection is higher on the body region.

From the other point of view, for the midfacial fracture, 9 plates were removed, 8 plates removed (28.5\%) in ZMC, and one plate (3.6\%) in maxillary fractures respectively. This study had a similar rate of removal for plate exposure to Nagase et al. (2005), who found that $72 \%$ of plates removed related with discomfort rather than infection to be the main cause for miniplate removal in traumatic midfacial fractures and this study resulted in differs from Francel et al. (1992) who found that infection and exposure were common in zygomatic buttress plates.

In our study, it had been significantly found that infection/wound dehiscence was more frequent with mandibular fractures than mid facial 
$(\mathrm{P}=0.028)$, while discomfort was significantly more frequent with midfacial fractures than mandibular, $(\mathrm{P}=0.013)$, and no significant difference had been found in plate exposure $(\mathrm{P}=0.62)$.

\section{Conclusion}

According to this study, there will be a need for hardware removal in a portion of patients treated with metallic osteosynthesis devices. This study states that the infection is most common reason for plate removal, followed by discomfort due to cold/heat climate, particularly in those facial regions that provide only thin soft tissue cover over the plate.

\section{References:}

1. Al-Khateeb, T., \& Abdullah, F. M. (2007). Craniomaxillofacial Injuries in the United Arab Emirates: A Retrospective Study. Journal of Oral and Maxillofacial Surgery, 65(6), 1094 - 1101.doi: 10.1016/j.joms.2006.09.013

2. Bakathir, A. A., Margasahayam, M. V., \& Al-Ismaily, M. I. (2008). Removal of bone plates in patients with maxillofacial trauma: a retrospective study. Oral Surgery, Oral Medicine, Oral Pathology, Oral Radiology, and Endodontology, 105, 32-37.doi: 10.1016/j.tripleo.2008.01.006

3. Baker, S., Dalrymple, \& Betts, N. (1997). Concepts and technique of rigid fixation. Textbook of Oral and Maxillofacial Trauma (second edition ed., Vol. II). (R. Fonseca, \& R. Walker, Eds.) W.B. Saunders Company.

4. Bhatt, V., \& Langford, R. J. (2003). Removal of miniplates in maxillofacial surgery: University Hospital Birmingham experience. Journal of Oral and Maxillofacial Surgery, 61(5), 553 - 556.doi: 10.1053/joms.2003.50108

5. Bolourian, R., Lazow, S., \& Berger, J. (2002). Transoral 2.0-mm miniplate fixation of mandibular fractures plus 2 weeks' maxillomandibular fixation: A prospective study. Journal of Oral and Maxillofacial Surgery, 60, 167-170.doi: 10.1053/joms.2002.29813

6. Chandra Shekar, B., \& Reddy, C. (2008). A five-year retrospective statistical analysis of maxillofacial injuries in patients admitted and treated at two hospitals of Mysore city. Indian Journal of Dental Research, 19(4), 304-308.doi: 10.4103/0970-9290.44532

7. Chritah, A., Lazow, S. K., \& Berger, J. R. (2005). Transoral 2.0-mm Locking Miniplate Fixation of Mandibular Fractures Plus 1 Week of Maxillomandibular Fixation: A Prospective Study. Journal of Oral and Maxillofacial Surgery, 63(12), $1737 \quad$ - 1741. doi:10.1016/j.joms.2005.08.022 
8. Dimitroulis, G. (2002). Management of fractured mandibles without the use of intermaxillary wire fixation. Journal of Oral and Maxillofacial Surgery , 60(12), $1435 \quad$ - 1438. doi:10.1053/joms.2002.36100

9. ELLIS III, E. (1993). Rigid skeletal fixation of fractures. Journal of Oral and Maxillofacial Surgery, 51(2), 163-173.

10. Francel, T. J., Birley, B. C., Ringelman, P. R., \& Manson, P. N. (1992). The Fate of Plates and Screws after Facial Fracture Reconstruction. Plastic \& Reconstructive Surgery, 90(4), 568-573.

11. Goyal, M., Jhamb, A., Chawla, S., Marya, K., Dua, J. S., \& Yadav, S. (2012). A Comparative Evaluation of Fixation Techniques in Anterior Mandibular Fractures Using $2.0 \mathrm{~mm}$ Monocortical Titanium Miniplates Versus $2.4 \mathrm{~mm}$ Cortical Titanium Lag Screws. Journal of Maxillofacial and Oral Surgery, 11(4), 442-450.doi: 10.1007/s12663012-0342-1

12. Goyal, M., Marya, K., Chawla, S., \& Pandey, R. (2011). Mandibular Osteosynthesis: A Comparative Evaluation of Two Different Fixation Systems Using $2.0 \mathrm{~mm}$ Titanium Miniplates and 3-D Locking Plates. Journal of Maxillofacial and Oral Surgery, 10(4), 316-320.doi: 10.1007/s12663-010-0087-7

13. Kumaran, P. S., \& Thambiah, L. (2011). Versatility of a single upper border miniplate to treat mandibular angle fractures: A clinical study. Annals of Maxillofacial Surgery, 1(2), 160-165.doi: 10.4103/22310746.92784

14. LEE, J. H., CHO, B. K., \& PARK, W. J. (2010). A 4-year retrospective study of facial fractures on Jeju, Korea. Journal of Cranio-MaxilloFacial Surgery, 38(3), 192-196.doi: 10.1016/j.jcms.2009.06.002

15. Longwe, E. A., Zola, M. B., Bonnick, A., \& Rosenberg, D. (2010). Treatment of mandibular fractures via transoral $2.0-\mathrm{mm}$ miniplate fixation with 2 weeks of maxillomandibular fixation: A retrospective study. Journal of Oral and Maxillofacial Surgery, 68(12), 29432946.doi: 10.1016/j.joms.2010.07.068

16. MALANCHUK, V. O., \& KOPCHAK, A. V. (2007). Risk factors for development of infection in patients with mandibular fractures located in the tooth-bearing area. Journal of Cranio-Maxillofacial Surgery, 35(1), 57-62.doi: 10.1016/j.jcms.2006.07.865

17. Nagase, D. Y., Courtemanche, D. J., \& Peters,, D. A. (2005). Plate Removal in Traumatic Facial Fractures: 13-Year Practice Review. Annals of Plastic Surgery, 55(6), 608-611.

18. Pohchi, A., Abdul Razak, N. H., Rajion, Z. A., \& Alam, M. K. (2013). Maxillofacial Fracture at Hospital Universiti Sains Malaysia (HUSM): 
A Five Year Retrospective Study. International Medical Journal, 20(4), 487-489.

19. Prabhakar, C., Shetty, J. N., Hemavathy, O., \& Guruprasad, Y. (2011). Efficacy of 2-mm locking miniplates in the management of mandibular fractures without maxillomandibular fixation. National Journal of Maxillofacial Surgery, 2(1), 28-32.doi: 10.4103/0975-5950.85850

20. Rana, Z. A., Khoso, N. A., Siddiqi, K., \& Farooq, M. U. (2012). The Incidence and Indications for removal of Osteosynthesis Devices in Adult Trauma Patients: A Retrospective Study. Annals of Pakistan Institute of Medical Sciences, 8(3), 179-182.

21. REHMAN, A.-U., KHAN, M., DIN, Q. U., \& BABAR, B. Z. (2009). FREQUENCY AND REASONS FOR THE REMOVAL OF STAINLESS StEEL PLATES IN MAXILLOFACIAL TRAUMA. Pakistan Oral \& Dental Journal, 29(2), 215-220. 